\title{
PENGARUH HIJAB PEREMPUAN PADA TATA RUANG RUMAH TINGGAL MUSLIM
}

\author{
Sukmayati Rahmah \\ Jurusan Teknik Arsitektur UIN Maliki Malang \\ Email:sukma.az@gmail.com \\ Telepon: 081334896248
}

\section{Abstract}

Women are the beings who guarded her nakedness than most men. So women have a more privacy rooms than others. By keeping the hijab as much as possible, the activities of the household can work well without fear of nakedness is maintained. It is very clear that in islamic law, the orders keep the hijab has been described in the Holy of Quran and Sunnah. So the role of architectural space is very important in presenting a space that could keep the nakedness of women in the home. As we know that space as a place of human activities, one of which is accommodating the activity of female residents in homes with a due regard to any restriction or hijab women in islam. This paper uses the theory as a method of approach and observe the formation of the muslim family residential. So the study can show the attention to architectural form hijab women in spatial arrangement. Spatial planning with respect to public and private space, the circulation of the house and used a room divider has major role in maintaining and cover the nakedness of the inhabitants, especially women in home. Separation of public and private space as one of the applications that are close the genitals. So the concept of study of this theory can be reference in designing the lay out in residences are islamic.

Perempuan adalah insan yang paling banyak dijaga auratnya daripada laki-laki, sehingga perempuan memiliki tempat yang lebih privasi dibanding laki-laki. Dalam hukum Islam, perintah menjaga hijab telah dijelaskan dalam al-Quran dan sunnah. Sehingga peran ruang yang arsitektural sangat penting dalam menghadirkan sebuah ruang yang bisa menjaga aurat perempuan di rumah. Seperti kita ketahui bahwa ruang sebagai wadah aktivitas manusia, salah satunya adalah mewadahi aktivitas penghuni perempuan dalam rumah tinggal dengan tetap memperhatikan batasan atau hijab perempuan dalam Islam. Tulisan ini menggunakan 
metode pendekatan teori sebagai alat tinjaunya dan mengamati bentukan rumah tinggal dari keluarga muslim. Sehingga studi tersebut dapat menunjukkan bentuk arsitektural yang memperhatikan hijab perempuan pada penataan ruangnya. Penataan ruang dengan memperhatikan ruang publik dan privat, sirkulasi rumah serta pembatas ruang yang dipakai mempunyai peran besar dalam menjaga dan menutup aurat penghuni terutama perempuan didalam rumah. Pemisahan ruang publik dan privat sebagai salah satu aplikasi yang bersifat menutup aurat. Sehingga konsep dari telaah teori ini dapat menjadi sebuah acuan dalam merancang tata ruang pada rumah tinggal yang islami dan desain yang memperhatikan gender.

Keywords: privasi, hijab, perempuan, tata ruang

\section{Pendahuluan}

Rumah sebagai tempat berlindung dan tempat kembali dari berbagai aktivitas. Dengan kata lain rumah dapat pula dijadikan sebagai sarana istirahat, perlindungan dari bahaya, hujan, panas, sarana silahturahmi dan sarana belajar dan ibadah. Rumah berarti wilayah perempuan, dimana perempuan melakukan peran domestik, dengan berbagai macam tugas kerumah tanggaan ada dibawah kendalinya. Hubungan gender dengan rumah dapat mempengaruhi pembentukan dan pengelompokkan ruang dalam rumah tinggal. Dimana gender tidak hanya melakukan peran sebagai ibu dengan tugas sehari-harinya namun sudah berkembang ke ranah publik. Perempuan dalam memenuhi kebutuhan sosialnya, memerlukan interaksi dengan dunia di luar rumah, termasuk bertemu dengan orang-orang yang bukan muhrimnya di rumah.

Rumah tinggal islami adalah rumah tinggal yang berlandaskan nilai-nilai al Quran dan Hadist. Diantaranya adalah dengan pemahaman bahwa rumah tinggal dibangun sebagai penutup diri saat beraktivitas di dalamnya, sebagaimana yang terkandung dalam firman Allah Swt, dalam Surat al-Ahzab $\{33\}: 53$ (Farid, Yuli \& Asror, Miftahul; 2009). Hijab merupakan penutup diri dari pandangan orang lain yang tidak boleh melihat sesuatu yang diharamkan, yakni aurat-aurat yang harus dibuka di dalam rumah. Termasuk didalamnya adalah menjaga aurat perempuan. Ruang pada rumah tinggal memiliki fungsi, sifat yang digunakan sebagai tempat atau wadah untuk melakukan aktivitas sesuai dengan penghuninya, hijab 
perempuan sebagai salah satu yang mempengaruhi dalam terbentuknya sebuah ruang. Tata ruang rumah berdasarkan sifat ruang, fungsi pembatas dan sirkulasi dapat berwujud macam-macam, misalnya pendaerahan/zona publik, privat, penggunaan pembatas ruang, pengaturan sirkulasi, dan lainlain.

Tulisan ini akan mengungkapkan pengaruh hijab perempuan dan gender dalam pembentukan tata ruang rumah tinggal. Ada dua permasalahan dalam penelitian, pertama, bagaimanakah hijab perempuan dan peran perempuan dalam islam? Kedua, bagaimana menempatkan perempuan dalam tata ruang rumah tinggal islam? Adapun tujuan dari penelitian ini adalah pertama, untuk mengetahui penerapan tata ruang dalam rumah tinggal yang sesuai syariah perempuan dalam islam. Kedua, untuk mengetahui komponen fisik dari elemen-elemen pembatas antara ruang privat dan publik yang digunakan pada rumah tinggal islam.

\section{Dasar Hukum Hijab Perempuan dalam Perancangan Rumah Tinggal Islami}

Al-Quran dan al-Hadist merupakan pedoman hidup manusia dalam melakukan kegiatan. Al-Quran sebagai kitab suci agama islam, merupakan firman Allah yang tertulis, sedangkan Al Hadist adalah ucapan dan tingkah laku Nabi Muhammad Saw yang dijadikan sebagai pedoman untuk kehidupan. Karena itulah dalam merancang rumah tinggal sebagai muslim berupaya untuk melakukan pendekatan yang sesuai dengan ketentuan AlQuran dan Al Hadist, baik secara bentuk, tata ruang, dan konstruksinya.

Islam mengakui hak-hak perempuan di ranah publik, termasuk hak dan kebebasan mengemukakan pendapat, ikut pemilu, berdagang, menghadiri shalat berjamaah, ikut ke medan perang dan lain-lain. Dalam sejarah peradaban manusia bahwa Nabi Muhammad saw memelopori gerakan emansipasi perempuan (Arif, Syamsuddin, 2006). Adat istiadat dan segala bentuk-bentuk perlakuan yang merugikan dan menindas perempuan pada masa itu, lambat laun bisa ditinggalkan. Dalam al-Quran tidak ada satu ayatpun yang menampakkan bias gender. Perempuan dan laki-laki diposisikan setara, hanya saja perempuan diciptakan menjadi manusia yang paling banyak harus menjaga auratnya daripada laki-laki. Perintah menjaga aurat tersebut dimaksudkan untuk memuliakan perempuan, tanpa membatasi aktifitas muslimah didalam masyarakat. 
Pada dasarnya perempuan adalah makhluk sosial yang memerlukan interaksi dengan individu lain sebagai upaya memenuhi kebutuhan sosialnya. Perempuan sebagai manusia tidak bisa melepaskan diri dari keterikatannya dengan manusia lain. Pada masa Rasulullah saw, perempuan dan laki-laki boleh mengucapkan salam, bertemu di masjid, bertemu dalam amar makruf nahi munkar, menuntut ilmu, pesta perkawinan, membesuk orang sakit dan lain-lain. Namun secara kodrati dalam melakukan interaksi tersebut ada batasan-batasan yang perlu diketahui dan kemudian ditaati oleh perempuan sebagaimana yang tercantum dalam al-quran dan al-hadist. Perempuan adalah insan yang paling banyak harus menjaga auratnya, oleh karena itu dasar dan batasan-batasan mengenai aurat perempuan perlu diketahui oleh setiap perempuan. Berkaitan dengan interaksi antar individu lain, Islam mengajarkan untuk menjalankan silahturahmi sebagai upaya untuk mempererat persaudaraan dengan sesama. Melalui silahturahimi tercipta suasana yang harmonis dalam masyarakat muslim pada khususnya dan masyarakat luas pada umumnya.

Masyarakat yang harmonis tercipta dari keluarga yang harmonis dan dari peran seorang perempuan dalam keluarga, seperti yang disebutkan dalam sebuah hadist bahwa "Perempuan itu ibarat sekolah jika kalian mendidiknya dengan baik berarti kalian sedang mempersiapkan sebuah bangsa dengan baik". Termasuk dalam mentaati perintah dari Allah yaitu perintah memakai jilbab (hijab). Perintah memakai hijab bagi perempuan bertujuan untuk menghormati, memuliakan kaum perempuan dan menjaganya dari pandangan orang asing. Dalam hukum islam, al-hijab berarti pakaian penutup yang menutupi seluruh tubuh perempuan (Qadir, Abdul Manshur, 2012: 254). Dijelaskan dalam ayat al-hijab, Wahai Nabi, katakanlah kepada istri-istrimu, anak-anak perempuanmu, dan istri-istri orang mukmin, "Hendaklah mereka menutupkan jilbabnya ke seluruh tubuh mereka" (Al-Ahzab 33: 59). Ayat tersebut menjelaskan bahwa kaum perempuan dilarang memperlihatkan diri mereka dihadapan laki-laki asing. Bahkan, para sahabat Nabi mengatakan bahwa perempuan yang memakai al-hijab berarti termasuk orang-orang mukmin yang berpengetahuan, tapi jika tidak memakai adalah budak berlian. Berdasarkan perintah memakai al-hijab tersebut, maka dalam perancangan rumah tinggal islami, penentuan wilayah perempuan dengan wilayah publik dipisahkan dengan 
tegas tanpa menghilangkan kenyamanan dan keleluasaan perempuan dalam beraktivitas.

\section{Tata Ruang Rumah Islami}

Allah menjadikan untuk kamu rumah-rumah kamu sebagai tempat ketenangan (QS An-Nahl: 80). Rumahku adalah surgaku (baiti jannaati), islam menggambarkan rumah sebagai tempat tinggal keluarga yang didalamnya tercipta ruh spirit Islam dan menjunjung tinggi nilai-nilai islam di dalamnya. (Farid, Yuli \& Asror, Miftahul; 2009). Pada dasarnya konsep desain rumah islami adalah rumah yang dapat memberikan kenyamanan dengan menjaga privasi penghuni rumah dan menjaga silahturahmi dengan lingkungan sekitar. (Junara, Nunik \& Putrie, Yulia Eka; 2009) terdapat beberapa tuntunan interaksi antar para penghuni, sebagai berikut; (1) privasi orang tua terhadap penghuni lainnya, (2) privasi antar anak (3) privasi penghuni terhadap tamu dan kerabat yang bukan mahram (4) privasi tamu, kerabat dan pembantu yang bukan mahram. Tuntunan tersebut terkait dengan konsep dalam Islam yang mengenal silahturahmi dan aurat yaitu bagian tubuh yang tidak boleh terlihat, sehingga ada konsep pemisahan zona yang tegas antara ruang satu dengan ruang yang lain terkait dengan zona privat dan zona publik dalam rumah. Dengan rumah yang memakai pembatas ruang, seorang tamu yang memasuki rumah lewat pintu depan tidak akan melihat aktivitas di dalam rumah, termasuk penghuni perempuan yang tidak berhijab.

Sistem pembatasan ruang dalam perancangan tata ruang islami dilakukan dengan penataan berdasarkan fungsi ruang yang bersifat umum (interaksi dengan lingkungan) dan ruang yang sifatnya pribadi atau privat. Pemisahan berdasarkan kelompok ruang tersebut dapat berupa elemen pembatas yang fungsinya sebagai penutup untuk membatasi pandangan menuju dalam rumah yang bersifat privat. Elemen pembatas ruang antara ruang publik dan privat secara fisik beragam jenisnya, baik yang permanen berupa dinding masif, jendela, pintu atau yang tidak permanen antara lain dengan partisi kaca, kayu, kain dan perabot. Selain itu, pemisahan zona dapat dilakukan dengan pengaturan jarak antar ruang dan penataan orientasi dan hubungan antar ruang (Junara, Nunik \& Putrie, Yulia Eka; 2009). 


\section{Fungsi dan Organisasi Ruang}

Rumah tinggal islami selain fungsinya sebagai tempat berlindung dan kembali dari berbagai aktivitas, juga sebagai wadah yang sesuai dengan kebutuhan bagi penghuni rumah, sehingga dalam memenuhi kebutuhan ruangnya benar-benar menyesuaikan dengan keinginan penghuni. Dengan kata lain bahwa kebutuhan penghuni sudah terfasilitasi semua didalam rumah, seperti kebutuhan untuk tidur, kebutuhan untuk makan, kebutuhan untuk berkumpul keluarga, kebutuhan untuk beribadah, kebutuhan untuk berinteraksi atau silahturahmi dengan tetangga, kebutuhan untuk perkembangan anak, dan lain sebagainya. Terkait dengan pengorganisasian ruang, dalam islam ada beberapa hadist dan firman Allah (QS An-Nur $\{24\}$ : 58) yang menjelaskan adanya perintah pemisahan tempat tidur antara anggota keluarga kecuali suami istri. Pemisahan tempat tidur menunjukkan adanya ruang privasi dalam islam. Selain itu adab-adab islam semisal meminta ijin dalam memasuki wilayah masing-masing menunjukan juga bahwa dalam islam mengenal adanya ruang-ruang privasi dalam rumah. Berdasarkan tuntunan interaksi antar para penghuni rumah dan luar rumah, fungsi dan organisasi ruangnya adalah dengan membagi zona privasi dan zona publik. Yang termasuk zona privasi dapat dilihat dari kebutuhan penghuni dan tuntunan interaksinya kepada siapa, misalnya kamar tidur, kamar mandi tidak memerlukan interaksi antar para penghuni didalam ruang tersebut, ruang makan dan dapur, merupakan kebutuhan penghuni untuk memenuhi kebutuhan pangannya dan memerlukan interaksi antar penghuni dan tidak interaksi dengan luar penghuni sehingga sifatnya privasi dari luar rumah namun bersifat publik untuk dalam rumah. Begitu juga dengan ruang santai atau ruang keluarga sebagai tempat berinteraksi dan berdiskusi antar penghuni rumah yang sifatnya publik dalam rumah dan privasi dari luar rumah. Sama halnya dengan ruang keluarga, ruang ibadah juga sebagai ruang publik bagi penghuni dalam rumah untuk melakukan ibadah berjamaah. Sedangkan untuk ruang yang bersifat publik adalah ruang yang interaksinya dilakukan oleh para penghuni rumah dengan orang luar rumah, yang bukan mahramnya, disediakan ruang untuk tamu. Dengan demikian organisasi ruang dalam rumah tinggal islam dibagi menjadi tiga bagian yaitu bagian untuk publik atau orang asing (orang yang bukan mahramnya), bagian untuk bersama bagi penghuninya dan bagian untuk pribadi yang bersifat sangat privasi. 


\section{Elemen Pembentuk Ruang}

Menurut Aristoteles, ruang adalah sebagai tempat (topos) sebagai suatu dimana, atau suatu place of belonging, yang menjadi lokasi yang tepat dimana setiap elemen fisik cenderung berada (Cornelis van de ven; 1995). Ruang tidak dapat dipisahkan dari kehidupan manusia baik secara emosi maupun fisik dimensi. Manusia berada dalam wadah untuk melakukan aktifitasnya yaitu ruang. Secara arsitektural, elemen pembentuk ruang, dibagi menjadi tiga yaitu lantai, dinding/pembatas, dan langitlangit. Lantai merupakan unsur pembentuk ruang yang dapat menentukan batas-batas ruang dan berfungsi sebagai alas sebuah ruang, begitu juga dengan dinding atau pembatas yang berfungsi sebagai pemisah antara ruang satu dengan ruang lainnya, dapat berupa dinding permanen ataupun non permanen. Sedangkan langit-langit atau atap berfungsi melindungi ruang-ruang dari pengaruh iklim. Setiap unsur elemen pembentuk ruang tersebut mempunyai pengaruh yang besar terhadap pola perilaku penghuni rumah tersebut. Oleh karena itu sebagai umat Islam, agar terwujud pola perilaku yang bernilai islam hendaknya dalam menggunakan elemen pembentuk ruang tersebut meninjau terlebih dahulu apakah nilai-nilai Islam, di antaranya perintah berhijab sudah dikaitkan.

\section{Pengaruh Hijab Perempuan pada Tata Ruang Rumah Tinggal Muslim}

Sebagai umat muslim, ajaran-ajaran agama Islam diwujudkan dalam perancangan rumah tinggal. Di rumah yang islami, di dalamnya menerapkan dan melaksanakan semua ajaran-ajaran Islam bagi para penghuninya baik untuk pribadi maupun sosial. Salah satu ajaran dari agama Islam adalah mengenal perintah hijab untuk perempuan. Dalam fikih Islam, al hijab berarti pakaian penutup yang menutupi seluruh tubuh perempuan. Tujuannya adalah untuk memuliakan perempuan itu sendiri dan menjaganya dari pandangan orang asing atau yang bukan mahramnya. Kaitannya dalam penataan rumah tinggal adalah rumah yang dapat menutupi dan membatasi pandangan orang yang bukan mahramnya terhadap penghuni perempuan. Dalam rumah tinggal islami dituntut untuk menciptakan sebuah rumah yang dapat menjaga hijab perempuan, sehingga kenyamanan dan keleluasaan dalam beraktivitas tidak terganggu. Pemisahan berdasarkan 
zona privat dan publik adalah sangat tepat. Kewajiban dalam perintah memakai hijab (jilbab) di luar rumah atau bertemu bukan mahromnya membentuk sistem pembatasan ruang dalam rumah. Oleh karena itu fungsi dari pembatas ruang permanen atau non permanen adalah sebagai hijab khususnya hijab perempuan. Ditinjau dari pembagian zona dalam rumah tinggal Islam adalah ada zona privat dan publik, dimana masingmasing zona yang membedakannya adalah interaksi pengguna ruangan. Pengaruh dari perintah hijab pada perempuan, menuntut kreatifitas dalam merancang atau menata ruang menjadi tempat atau wadah beraktifitas yang nyaman tanpa meninggalkan syariat hijab tersebut. Zona/wilayah publik yang memerlukan perhatian khusus dalam peletakannya dan penataannya, antara lain ruang tamu. Ruang tamu adalah ruang untuk menerima tamu. Islam sangat menganjurkan umatnya untuk menghormati dan memuliakan tamu. Betapa pentingnya tamu dan silahturahim bagi umat Islam, sehingga ruang tamu hendaknya ditata senyaman mungkin. Kondisi nyaman yang dimaksud adalah seminimal mungkin tamu tidak mendengar dan melihat apa yang sedang dilakukan penghuni rumah khususnya penghuni perempuan atau sebaliknya, dengan kedatangan tamu tersebut, penghuni rumah yang lain tetap bisa melakukan aktivitasnya dalam rumah. Begitu juga dengan ruang privasi lainnya seperti kamar tidur, khususnya untuk ruang tidur perempuan, tingkat privasinya lebih tinggi karena auratnya lebih banyak perlu dijaga daripada laki-laki. Selain itu kamar tidur sebagai zona privasi karena diperuntukkan sebagai tempat beristirahat yang membutuhkan ketenangan. Pemisahan zona yang sangat tepat tersebut juga membuktikan adanya pertimbangan menjaga hijab perempuan. Aplikasi pemisahan zonanya dengan menggunakan pembatas ruang yang permanen yaitu berupa dinding bata, kaca dan pintu, juga dapat sebagai pencahayaan dan akses masuk menuju ruang keluarga. Selain itu penerapan pembatas dengan menggunakan perabot adalah sebagai upaya untuk menjaga hijab perempuan dalam rumah.

Pembahasan dalam tulisan ini dimulai dengan mengamati beberapa rumah tinggal keluarga muslim yang berada di kota Malang dan Jember. Dimana rumah tinggal yang dipiih adalah rumah tinggal yang penghuninya terdiri dari orang tua, anak laki dan perempuan. Beberapa tipe yang dipilh adalah tipe 54, 70, dan 100. Tipe 54 dengan luas bangunan $54 \mathrm{~m}^{2}$ dan luas 
tanah $120 \mathrm{~m}^{2}$, tipe 70 dengan luas bangunan $70 \mathrm{~m}^{2}$ dan luas tanah $150 \mathrm{~m}^{2}$, tipe 100 dengan luas bangunan $100 \mathrm{~m}^{2}$ dan luas tanah $300 \mathrm{~m}^{2}$. Berikut adalah hasil pengamatan terhadap peletakan ruang privasi, publik dan elemen pembatas, dengan disusun berdasarkan denah rumah tinggal dan dokumentasi berupa foto-foto.

Rumah Tinggal Tipe 54

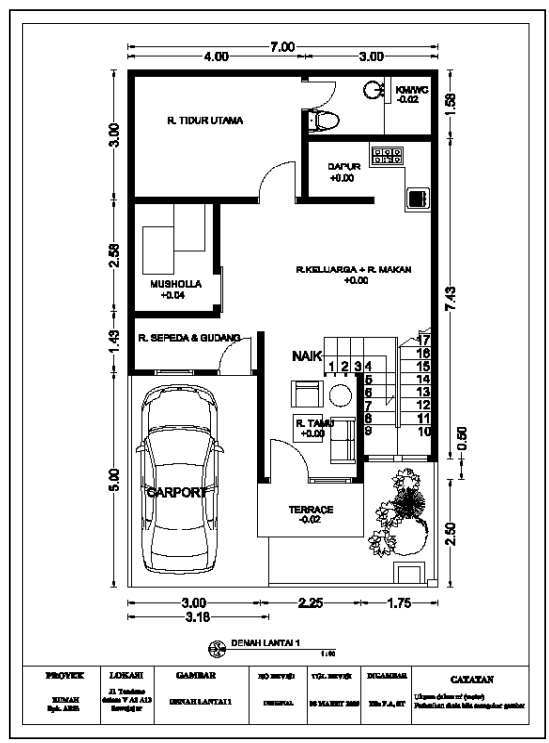

Denah ruang tipe $54 \mathrm{a}$

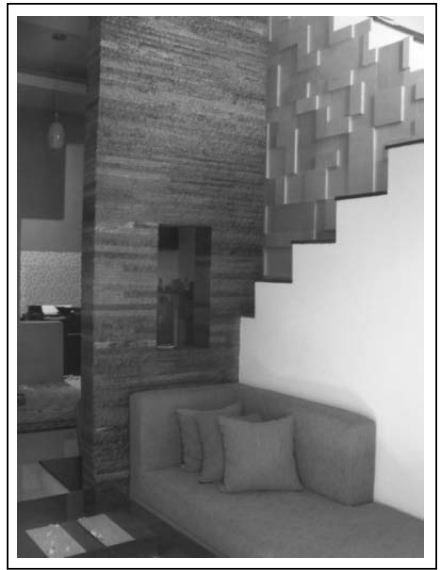

Pandangan dari ruang tamu

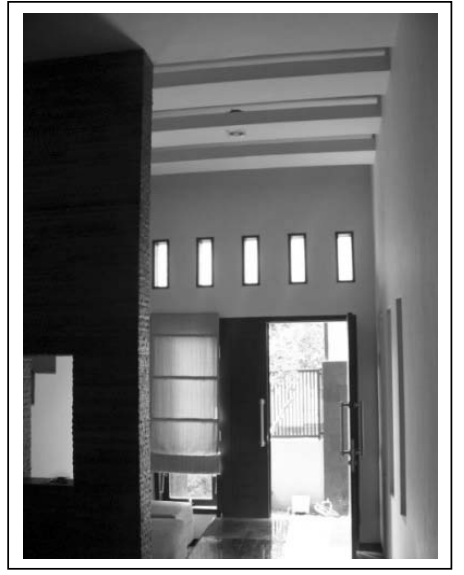

Pandangan dari ruang keluarga

Gambar 1. Sumber penulis (2007 \& 2012) 


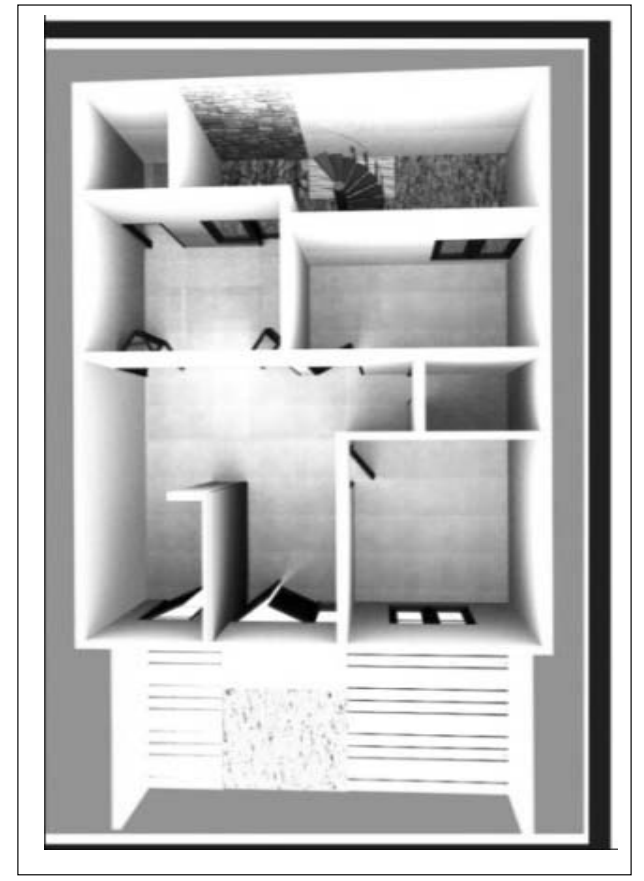

Denah rumah tipe $54 \mathrm{~b}$

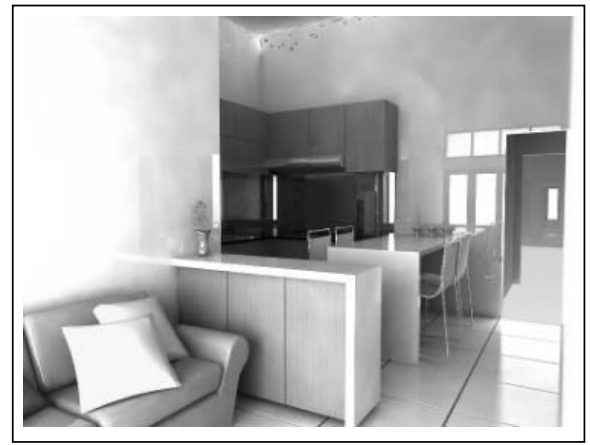

Pandangan dari ruang tamu

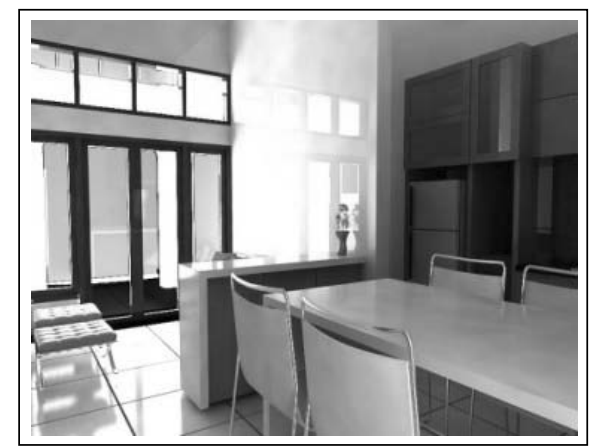

Pandangan dari ruang keluarga \& ruang makan

Gambar 2. Sumber penulis (2007 \& 2012)

Rumah diatas merupakan rumah tipe 54, sebagai sampel dalam penelitian ini ada dua model tipe 54a dan tipe 54b yang lokasinya berada di kota Malang, yaitu jalan danau tondano, perumahan sawojajar dan pondok kopi. Denah rumah dibagi menjadi dua zona/wilayah yaitu zona publik 
dan privat. Pemisahan zona berupa dinding pembatas yang berlubang antar ruang tamu sebagai ruang publik dengan ruang keluarga sebagai ruang privat. Pemisahan tidak berupa dinding masif dikarenakan luas ruang tamu yang terbatas, agar tidak terasa sempit ada tampilan permainan pada dinding pembatas. Elemen pembatas yang digunakan adalah dinding bata berlubang dan penggunaan perabot lemari. Dengan pemisahan zona dan pemakaian elemen pembatas tersebut, aktifitas perempuan di ruang keluarga tidak terlalu terganggu, auratnya dapat terjaga walaupun tidak sempurna. Namun untuk area yang lebih privat seperti kamar tidur, dipisahkan dengan orientasi pintu kamar yang tidak langsung mengarah pada ruang tamu, sehingga privasi penghuni kamar lebih terjaga.

Rumah Tinggal Tipe 70

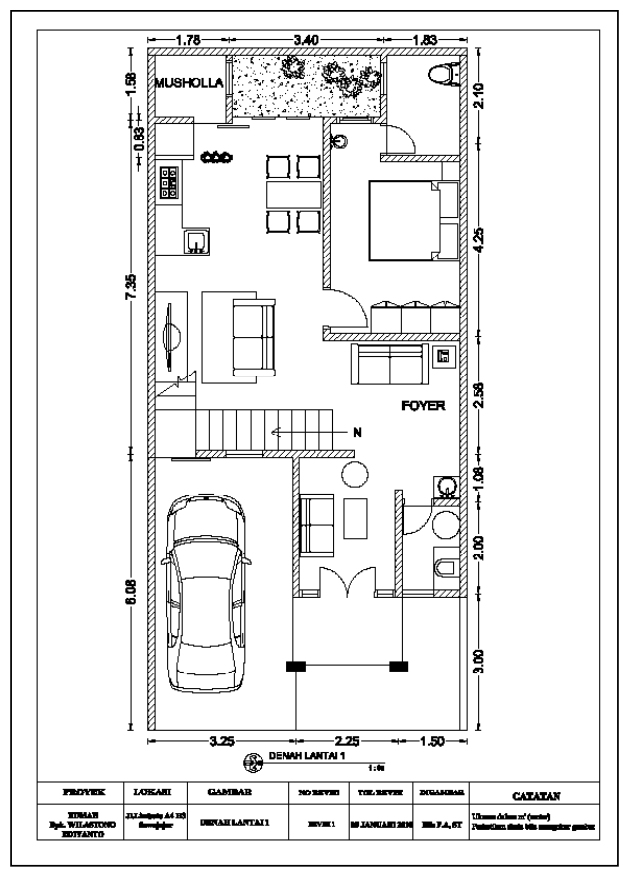

Denah rumah tipe 70 


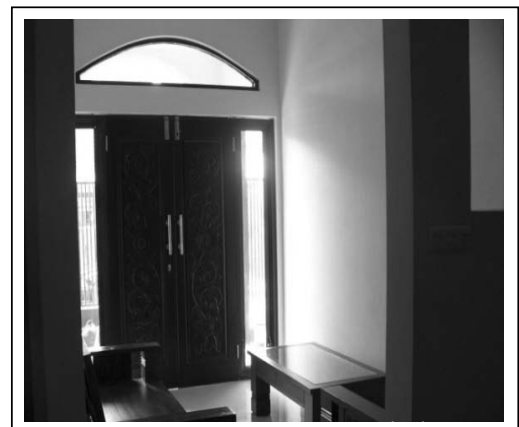

Pandangan dari ruang keluarga

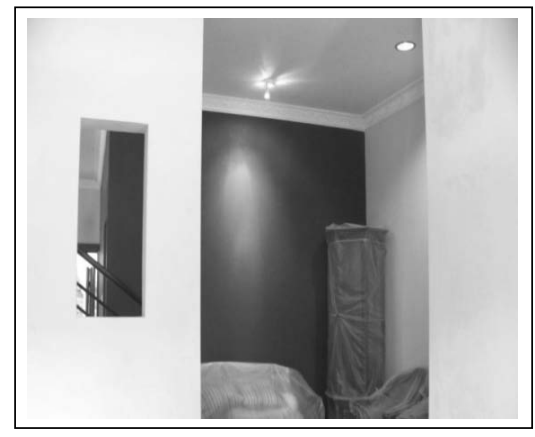

Pandangan dari ruang tamu

Gambar 3. Sumber penulis 2007

Rumah tipe 70 dengan luas tanah $150 \mathrm{~m}^{2}$ dan luas bangunan 70 $\mathrm{m}^{2}$ berada di perumahan Sawojajar jalan danau limboto. Pembagian zona publik dan privat pada rumah tinggal tipe 70 adalah pemisahan wilayah dengan menggunakan dinding bata berlubang sebagai penutup antara ruang tamu dengan foyer menuju ruang keluarga. Secara fungsi dinding dan area sirkulasi sebagai foyer tersebut sudah berfungsi sebagai hijab. Namun pemisahan antara ruang privat dan ruang keluarga sangat jelas, hal ini terlihat dengan adanya pemisahan antara ruang tamu dengan ruang keluarga yang memakai elemen pembatas dinding bata berlubang, juga di tambah dengan adanya foyer sebagai perantara antara ruang tamu dan ruang keluarga. Sehingga ruang keluarga lebih terjaga privasinya, dan penghuni rumah terutama perempuan dapat melakukan aktivitasnya dengan nyaman.

\section{Rumah Tinggal Tipe 100}

Pengaruh ajaran Islam yang mengenal perintah hijab bagi perempuan pada penataan ruang-ruangnya dapat dilihat dari penempatan ruang publiknya yang sangat tepat, seperti pada rumah tinggal tipe 100 dengan lokasi di perumahan Pondok Gede Permai Jember. Pemisahan area publik dan privat sangat tegas. Dengan adanya pembatas dinding bata dan tirai yang menuju ruang keluarga dengan sirkulasi yang tidak langsung menghadap ruang keluarga mampu menutup, baik secara visual maupun audio bagi penghuni didalam rumah ketika ada tamu. Sedangkan pada area ruang kerja yang merupakan publik, penggunaan elemen pembatas 
berupa dinding bata dan pintu sebagai penghubung dengan ruang tamu juga mampu menutup secara optimal bagi area privasi.

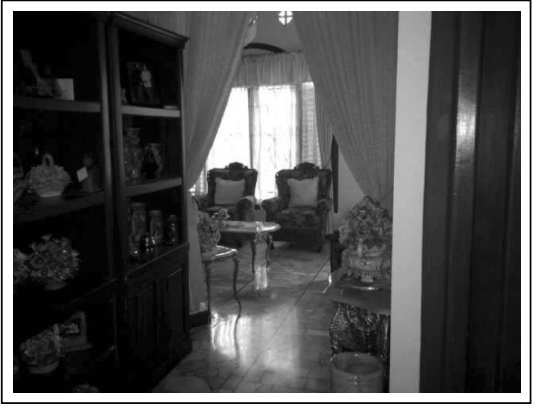

Pandangan dari ruang keluarga

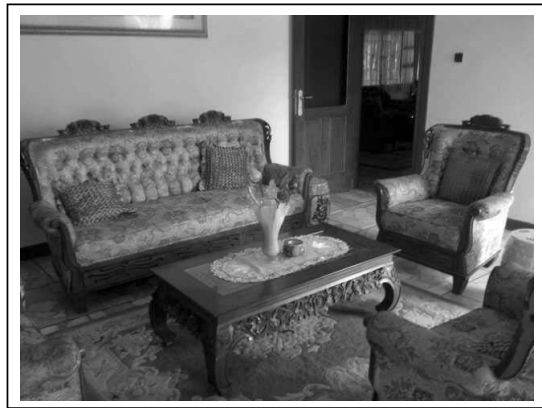

Pandangan dari ruang kerja menuju ruang keluarga

Gambar 4. Sumber penulis 2012

\section{Penutup}

Ruang pada rumah tinggal Islam memiliki fungsi, sifat, yang digunakan untuk melakukan kegiatan sesuai keinginan para penghuni rumah. Perempuan sebagai pusat keluarga yang selama ini memegang peran domestik utama dalam rumah tinggal mempengaruhi pembentukan ruang dan pengelompokkan ruang dalam rumah tinggal. Peran domestik berkembang dan bergeser menjadikan sebuah rumah sebagai ruang publik bagi perempuan memberikan makna lain pada rumah tinggal.

Ajaran Islam sangat memuliakan perempuan, dalam hal ini adalah mengenai hijab perempuan sebagai salah satu syariat yang dijadikan acuan dalam menata ruang dalam rumah tinggal. Aplikasi penataan ruang yang menjaga hijab perempuan adalah dengan pemisahan zona/wilayah publik dan privat. Selain itu pemakaian dan pemilihan jenis elemen pembatas juga sebagai unsur yang menentukan ruang tersebut menjadi privasi atau tidak. Dapat diambil kesimpulan bahwa peran gender dalam rumah tinggal adalah tidak hanya sebagai peran domestik namun sebagai pemenuhan kebutuhan sosial bagi perempuan untuk berinteraksi dengan nyaman dan menjadikan rumah bermanfaat bagi seluruh penghuni rumah. Dilihat dari komponen fisik tata ruang pada rumah tipe kecil dan tipe sedang pembagian zona sudah dilakukan, namun fungsi pembatas ruang tidak sempurna 
sebagai hijab. Sedangkan rumah tipe besar, penerapan ruang publik dan privat sudah tepat, didukung pula dengan pemilihan elemen pembatas yang berfungsi sebagai hijab. Penggunaan dinding bata dan dinding pintu mampu menutup hijab perempuan baik secara visual maupun audio. Peletakkan ruang publik yang dipisahkan dengan ruang privat adalah salah satu alternatif yang sangat tepat, sehingga ruang publik sebagai ruang sosial perempuan dan interaksi dengan orang luar rumah dapat terwadahi dengan nyaman.

Dalam penelitian ini penekanan zona publik dalam rumah tinggal adalah berupa ruang tamu, dimana pelaku aktifitasnya adalah orang luar sebagai tamu dan penghuni, sehingga peletakan ruang tersebut diupayakan nyaman bagi keduanya. Dari pengamatan ketiga tipe rumah tersebut, bahwa rumah tinggal yang menjaga hijab penghuni perempuan dengan sempurna adalah rumah dengan penataan ruang yang memisahkan antara ruang tamu dengan ruang keluarga yang menggunakan elemen masif berupa dinding baik material bata, kayu, beton atau berupa pintu. Untuk rumah dengan lahan yang luas tidak terlalu sulit dalam memisahkannya. Lain halnya dengan tipe rumah yang lahannya terbatas. Ruang tamu dapat dirancang semi terbuka, menyatu dengan teras. Sehingga dari segi pencapaian lebih mudah dan nyaman. Tamu dapat langsung berinteraksi di ruang teras yang sekaligus sebagai ruang tamu.

Dengan perancangan rumah tinggal yang menempatkan ruangruang sesuai dengan fungsi dan penggunanya, ruang yang dihasilkan akan menjadi lebih bermakna dan bermanfaat. Dalam hal ini ruang perempuan yang dapat mewadahi kebutuhan sosialnya dalam rumah tinggal menjadi dasar dalam pembentukan ruang pada rumah tinggal. Kiranya perlu dipertimbangkan atau menjadi perhatian bagi arsitek-arsitek muslim khususnya dan pengguna untuk lebih memperhatikan gender dalam hal ini yaitu peran perempuan di ranah publik, tanpa melupakan syariah hijab perempuan dalam merancang rumah tinggal, khususnya pola tata ruang pada rumah tinggal.

\section{DAFTAR PUSTAKA}

Arif, Syamsuddin, 2006, "Menyikapi Feminisme dan Isu Gender”, A1 Insan, No 3, Vol 2, Jakarta. 
Farid, Yuli \& Asror, Miftahul, 2009, "Tata Desain Rumah Islami”, Diva Press, Jogjakarta.

Firstanty, Anddys \& Hidayat, Ade, 2010, "31 Inspirasi Rumah Islami”, Transmedia, Jakarta.

Junara, Nunik \& Putrie, Yulia Eka, 2009, “Rumah Ramah Lingkungan”, UIN Malang Press, Malang.

Mashur, Qadir, Abdul, Dr, 2012, “Buku Pintar Fikih Wanita”, Zaman, Jakarta.

Setiawan \& Haryadi, B, 2010, “Arsitektur Lingkungan dan Perilaku”, Gadjah Mada University Press, Yogyakarta.

Ven, Cornelis van de, 1995, “Ruang dalam Arsitektur”, PT Gramedia Pustaka Utama, Jakarta. 